日植病報 $41: 467-476$ (1975)

Ann. Phytopath. Soc. Japan $41: 467-476$ (1975)

\title{
Nature of Specific Susceptibility to Alternaria kikuchiana in Nijisseiki Cultivar among Japanese Pears $(\mathrm{V})^{*}$
}

\author{
Role of host-specific toxin in early step of infection \\ Hiroshi Otani**, Syoyo Nishimura**, Keisuke Kohmoto**, \\ Kiyoshi YANO** and Takeji SENo** \\ 尾谷 浩**.西村正暘**.甲元啓介** ・ 矢野 清** ・瀬野武治**：ナシ黒斑病菌の宿主 \\ 特異的作用機構 $(\mathrm{V})^{*}$ ナシ黒斑病感染初期に和ける宿主特異的毒素の役割
}

\begin{abstract}
Spore germination, mycelial growth and appressorial formation of Alternaria kikuchiana were similar on both susceptible and resistant Japanese pear leaves. A hostspecific toxin (AK-toxin) was synthesized and released from virulent spores immediately after germination. Four hr after inoculation, one germinating spore produced approximately $10^{-6} \mu \mathrm{g}$ toxin, which was capable of disturbing the metabolic activities of approximately 100 host cells. The first physiological event induced by germinating spore was an increased loss of electrolytes from susceptible leaves. This reaction was evident 2-6 hr after inoculation, indicating that the leakage was caused by AK-toxin from germinating spores prior to invasion. Penetration of epidermal cells was detected only in susceptible leavers 8-12 hr after inoculation with virulent spores. Hyphal growth was observed in the mesophyll tissues by $24 \mathrm{hr}$. Similar infection occurred on susceptible tissues when an avirulent isolate plus AK-toxin were used. It was found that citrinin exhibited similar host specificity and toxic behaviors on Japanese pear tissues. However, spores of Penicillium citrinum, which is a citrinin producer, was unsuccessful in invading pear leaves. A possible reason for this was the fact that citrinin can be produced only from the growing mycelia and not from the germinating spores. All these data suggest that AK-toxin from germinating spores prior to host invasion plays key role as an initial inciting agent of the disease establishment. (Received December 16, 1974)
\end{abstract}

\section{Introduction}

Alternaria kikuchiana Tanaka, the causal fungus of black spot of Japanese pear (Pyrus serotina Rehd.), produces a host-specific toxin (AK-toxin) ${ }^{3,14,15)}$. There are several lines of evidence which show that the toxin is a necessary determinant of pathogenicity and host-specificity for the pathogen. (i) Virulent isolates of A. kikuchiana produce AK-toxin in artificial cultures. Avirulent isolates have lost their ability to produce toxin $^{3,5)}$. (ii) AK-toxin is strikingly toxic to susceptible cultivars (Nijisseiki and its derivatives), but is harmless to resistant cultivars and to other non-host plants ${ }^{3,4,14,15)}$. (iii) All known physiological and biochemical changes induced by the pathogen infec-

* Studies on Black Spot Disease of Japanese Pear (Part VII). This research was supported in part by Scientific Research Expenditure, Ministry of Education, Japan, No. 886008 (1973 and 1974), No. 936006 (1974) and No. 976028 (1974).

** Faculty of Agriculture, Tottori University, Tottori, Japan. 鳥取大学農学部. 
tion can also be reproduced in the susceptible pear plant by the toxin ${ }^{9,15)}$. (iv) The susceptibility to the fungus and to its toxin is controlled by a single dominant gene ${ }^{6}$. Therefore, Japanese pears susceptible and resistant to A. kikuchiana and AK-toxin allow for a simplified model to study host-parasite relationships.

The concept that host-specific toxin may be involved in initial colonization has been supported recently by several lines of evidence in some fungal saprophytic pathogens $^{1,16,17)}$. Our previous data showed that AK-toxin is synthesized and released from the germinating spores of $A$. kikuchiana ${ }^{9}$. The toxin produced by the pathogen causes a drastic increase in electrolyte loss from the host tissues during the infection process ${ }^{9}$. However, the significant evidence of AK-toxin action in early step of infection and mechanism whereby initial colonization occurs have remained to be elucidated. Brief reports of some of this work have been published ${ }^{8,12)}$.

\section{Materials and Methods}

Conidia of a high toxin-producing isolate (No. 15) of A. kikuchiana, and an avirulent isolate (No. 11) were produced and maintained as described previously9). Spores were washed thoroughly with distilled water by centrifuging and the spore concentration was adjusted to $10^{6}$ spores $/ \mathrm{ml}$ by adding distilled water or toxin solution. AK-toxin was prepared from culture filtrates by established procedures ${ }^{9,10)}$. Veinal necrosis was produced on susceptible pear leaves with $0.01 \mu \mathrm{g} / \mathrm{ml}$ of toxin.

Pear cultivars susceptible (Nijisseiki) and resistant (Chojuro) to A. kikuchiana and to its toxin were used in all experiments. Spore suspensions were sprayed on freshly harvested young pear leaves or on glass slides as controls. After incubation for specified time periods in a moist chamber at $28 \mathrm{C}$, the leaves were examined for fungal development.

In the test for release of AK-toxin from germinating spores, drops of spore suspension were placed on glass slides. At various times of incubation, the drops were harvested with a pipet and spores were removed by filtration. The filtrates were then bioassayed for host-specific toxicity. One drop of the filtrates was placed on a crossscratch of susceptible pear leaves. After $24 \mathrm{hr}$ incubation, the area of characteristic veinal necrosis on the leaves was measured. The dilution end point for induced necrosis from the filtrates was also determined by methods described previously ${ }^{9}$.

Pear leaves were sprayed with a spore suspension or with distilled water as a control. After incubation for various periods at $28 \mathrm{C}$, electrolyte leakage from the leaves was : measured by changes in electrical conductivity of the ambient solutions ${ }^{9}$.

Pear leaves inoculated with drops of a spore suspension were cross-sectioned at specified intervals with a Hooker plant microtome. The sections were transferred to glass slides and stained with $0.1 \%$ cotton blue in lactophenol. After rinsing with lactophenol, invasion of infection hyphae to pear leaf was examined under microscope.

Spores of Penicillium citrinum were prepared from cultures grown on potatodextrose-agar. The surface of the cultures was flooded with distilled water and stirred with a brush. After filtration through gaze, spores were collected by centrifuging, and then were suspended in $0.1 \%$ sucrose solution. Pear leaves were inoculated with a spore suspension. 


\section{Results}

\section{Behaviors of A. kikuchiana spores on pear leaves}

Spores of virulent A. kikuchiana sprayed on pear leaves, began to germinate at one hr after inoculation, and grew equally on susceptible and resistant pear leaves (Fig. 1, $\mathrm{A}$ and $\mathrm{B}$ ). Growth of the germ tubes was slower on pear leaves than on glass slides, because of formation of appressoria on the pear leaves (Fig. 1, B and C). Appressoria were formed both on resistant and susceptible pear leaves within $4 \mathrm{hr}$ after inoculation (Fig. 1, C). Germination, growth of germ tube and appressorial formation of the avirulent isolate on the leaf surfaces were the same as for the virulent isolate. There were no measureable differences in the behavior of the fungus on susceptible and resistant pear leaves.

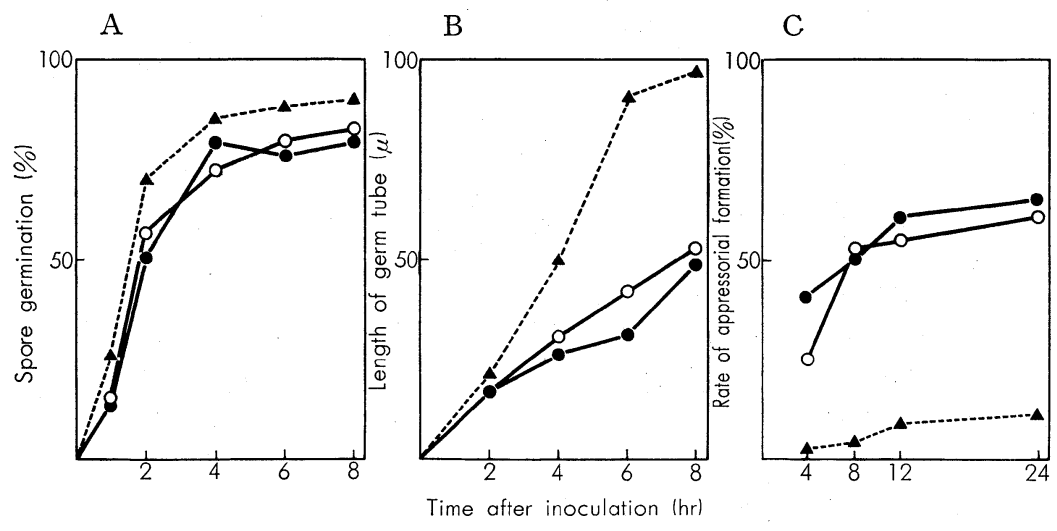

Fig. 1. Spore germination (A), growth of germ tube (B) and appressorial formation (C) of virulent $A$, kikuchiana on susceptible (- - ) and resistant (-O-) pear leaves, or on glass slides (-- - - ). Rate of appressorial formation was showed as per cent of number of appressoria per number of germ tubes.

Penetration of hyphae into pear tissues was investigated at various times after spore inoculation. In susceptible pear leaves inoculated with virulent spores, hyphal penetration into epidermal cells was observed within 8-12 hr after inoculation. After $24 \mathrm{hr}$, infection hyphae grew in the mesophyll tissues and some hyphae penetrated completely through the leaf. The black spots on host tissues were first evident $18 \mathrm{hr}$ after inoculation. Pear leaves from resistant plant showed little or no invasion from the pathogen. Similar results were indicated on both types of leaves using an avirulent isolate. Occasionally, a few epidermal cells were invaded by $24 \mathrm{hr}$ in younger leaves, but fungal growth stopped in the epidermal cells.

\section{AK-toxin release by spore germination and its toxicity on pear leaves}

Our previous data indicated that resting spores of A. kikuchiana do not contain AK-toxin, but synthesize and release it gradually during the germination ${ }^{9}$. To determine the amount of AK-toxin released from germinating spores and its toxic activity, more detailed experiments were designed. The toxicity of spore suspensions incubated for specified times were determined by measuring the dilution end point and area of the veinal necrosis induced (Fig. 2). The AK-toxin concentration of each spore- 
germinating fluid was calculated by applying the relationship curve between toxin concentration and host responses established previously ${ }^{4}$. The following formulas were used to calculate amount of AK-toxin released from one germinating spore and the number of necrotic host cells which were affected.

Formula I :

Amount of AK-toxin from one germinating spore $=$

AK-toxin concentration in spore-germinating drop $\times$ Drop volume Spore concentration $\times$ Drop volume $\times$ Rate of spore germination

Formula II :

Number of host cells which will be effected

by the toxin from one spore

$$
\frac{\frac{\text { Necrotic area induced }}{350^{\mathrm{a}}} \times 10 \text { cells }^{\mathrm{b})}}{\text { Spore concentration } \times \text { Drop volume } \times \text { Rate of spore germination }}
$$

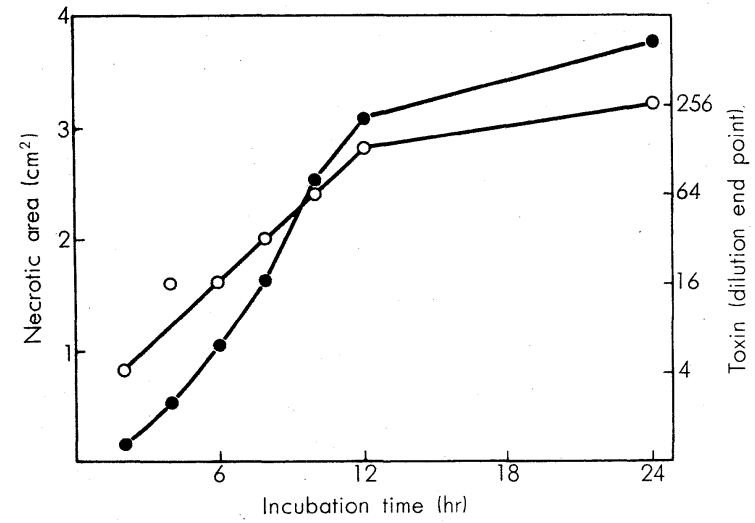

Fig. 2. Release of toxin from germinating spores in water on glass slides. Activity of toxin was showed as area of veinal necrosis (- - ) induced by the germination fluids, and as dilution end point $\left(-\mathrm{O}_{-}\right)$ of the germination fluids to cause veinal necrosis.

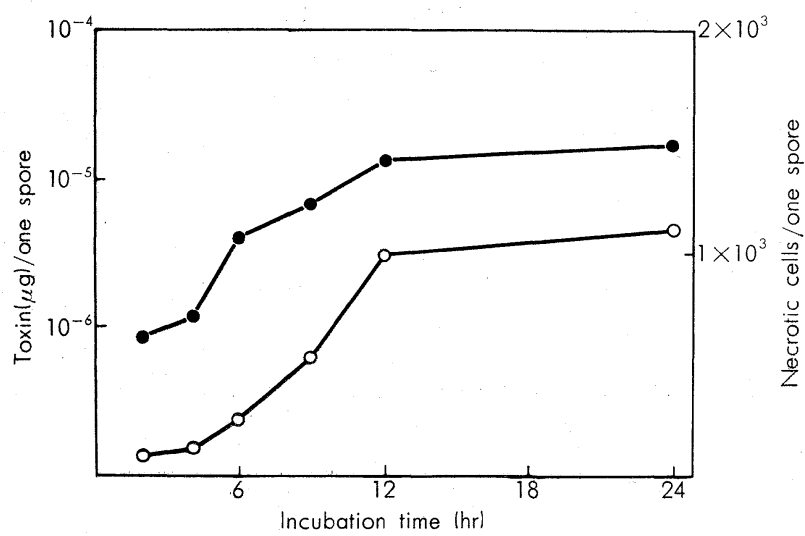

Fig. 3. Toxin amount released by germination of one spore and its toxic activity on susceptible pear cells. Toxin amount (- - -) and number of necrotic cells $\left(-\mathrm{O}_{--}\right.$) by one spore were calculated by formulas in the text. 
a) Section area $\left(\mu \mathrm{m}^{2}\right)$ of one host cell.

b) Number of cells between the cross-section of leaves.

Four hr after placing the spore drops on glass slides, one germinating spore yielded $10^{-6} \mu \mathrm{g}$ toxin from the germ tube and the amount of toxin appeared to be potent enough to cause necrosis of approximately 100 host cells (Fig. 3). The amount of AKtoxin from germinating spores increased gradually according to growth of germ tube, but reached almost constant value after $12 \mathrm{hr}$; growth of germ tube stopped on glass slides at this time.

\section{Effect of AK-toxin on formation of necrotic spots by spore inoculation}

Pear leaves were sprayed with a spore suspension and then incubated at $28 \mathrm{C}$ in a moist chamber. At specific time intervals of incubation, growth of the germ tubes on the leaves was stopped by spraying with a $0.08 \%$ difolatan solution. The sprayed leaves were successively incubated at $28 \mathrm{C}$. After $24 \mathrm{hr}$ of spore inoculation, the necrotic area induced by one spore was measured under the microscope and the number of necrotic cells was determined as follows :

Number of necrotic cells by one spore $=$

$$
\frac{\text { Necrotic area induced }}{350} \times 10 \text { cells. }
$$

Results showed that one pathogenic spore on host leaves was capable of inducing necrosis of approximately 100 host cells at $3 \mathrm{hr}$ after inoculation (Fig. 4). Although experiments on host leaves in Fig. 4 were different from experiments on glass slides in Fig. 3, results with both experiments were similar until $12 \mathrm{hr}$ after inoculation. Thus, it can be concluded that the AK-toxin from germinating spores was responsible for the necrotic spots. The number of necrotic cells increased on and after $12 \mathrm{hr}$ of spore inoculation (Fig. 4). It seems likely that the AK-toxin responsible for this was not from germinating spores, but from the invading hyphae.

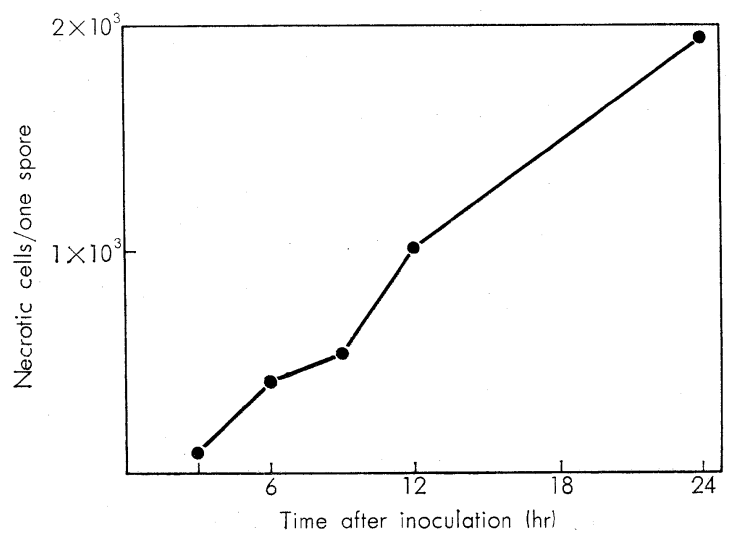

Fig. 4. Number of necrotic cells induced on susceptible pear leaves by inoculation of one spore. Pear leaves were inoculated with spores, incubated at $28 \mathrm{C}$ for times as indicated, and treated with difolatan. Area of necrotic spots were measured $24 \mathrm{hr}$ after inoculation, under microscope. Number of necrotic cells induced by one spore was caluculated by formula in the text. 


\section{Loss of electrolytes from pear leaves by spore inoculation}

AK-toxin is known to cause the almost instantaneous increase in loss of electrolytes from susceptible tissues ${ }^{4,9,10)}$. Such an increase in electrolyte loss was also observable during the infection process by the pathogen ${ }^{9}$. However, the physiological effect of AK-toxin on host cells must be observed prior to invasion into host tissues, since AK-toxin is secreted immediately after spore germination. Therefore, loss of electrolytes from pear leaves by spore inoculation was re-examined carefully. Susceptible leaves inoculated with virulent spores of A. kikuchiana, began to lose more electrolytes than control leaves at $2 \mathrm{hr}$ after inoculation (Fig. 5). The increase in electrolyte loss revealed the two different time phases: at $2-6 \mathrm{hr}$ and at $9 \mathrm{hr}$ after spore inoculation (Fig. 5). Electrolyte loss from resistant leaves inoculated with virulent spores, or susceptible and resistant leaves inoculated with spores from an avirulent isolate did not differ from non-inoculated controls (Fig. 5).

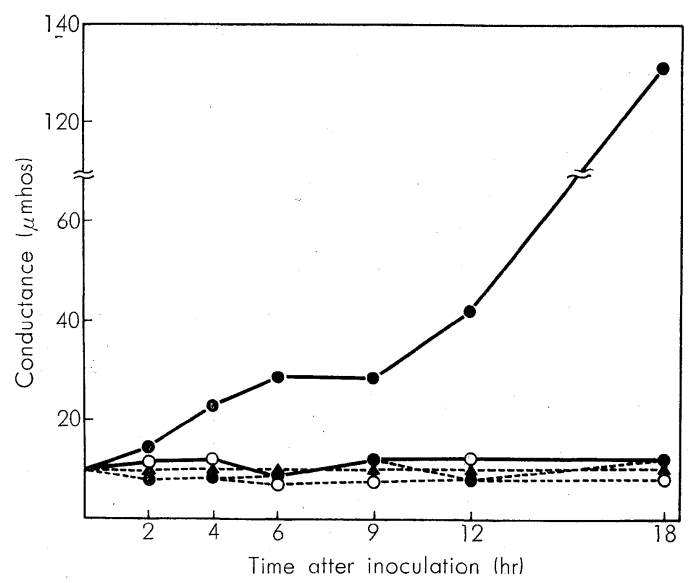

Fig. 5. Effect of spore inoculation on loss of electrolytes from pear leaves. Leaf samples were washed and suspended in glass-distilled water for one hr. Each conductance from pear leaves inoculated was adjusted by calculating the value of each water control to $10 \mu \mathrm{mhos}$, and was shown by the net value of increased electrolyte leakage from initial inoculation time till each specific interval. Treatments were as follows: - - - susceptible tissues inoculated with virulent spores; -- --, susceptible tissues inoculated with avirulent spores; $-\mathrm{O}$, resistant tissues inoculated with virulent spores; --O--, resistant tissues inoculated with avirulent spores; --- -- , susceptible and resistant tissues inoculated with water.

To know effect of AK-toxin on electrolyte loss by spore inoculation, pear leaves were inoculated with avirulent spore suspensions containing $0.1 \mu \mathrm{g} / \mathrm{ml} \mathrm{AK-toxin,} \mathrm{and}$ loss of electrolytes from pear leaves was measured at intervals. The inoculated susceptible leaves were induced the increase in loss of eletrolytes, just as did the virulent spore.

\section{Loss of electrolytes from pear leaves by AK-toxin from germinating spores}

An experiment was made to determine whether or not the amount of AK-toxin from germinating spores is enough to induce electrolyte loss from pear tissues. Filter 
paper $(10 \times 20 \mathrm{~cm})$ was sprayed with spore suspension $(4 \mathrm{ml})$ and incubated at $28 \mathrm{C}$. After various incubation periods, AK-toxin was extracted from the filter paper by a procedure described previously ${ }^{9}$, and the extracts were diluted to $4 \mathrm{ml}$ with distilled water. Pear leaves were vacuum-infiltrated for $15 \mathrm{~min}$ with the toxin solution and electrolyte loss from the leaves was measured. AK-toxin preparation obtained after $2 \mathrm{hr}$ incubation showed visible electrolyte leakage from susceptible leaves (Fig. 6).

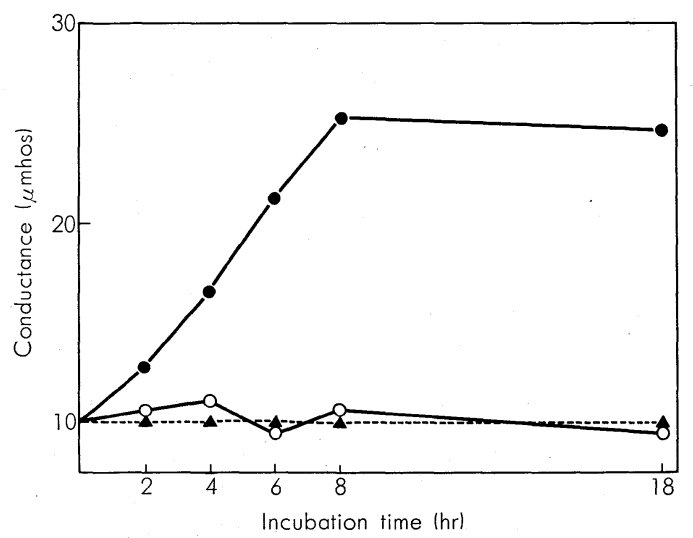

Fig. 6. Effect of AK-toxin from germinating spores on loss of electrolytes from pear leaves. Susceptible (- - ) and resistant (-O-) pear leaves were vacuum-infiltrated with AK-toxin solution extracted from germinating spores and suspended in glass-distilled water for one hr. Conductance of each ambient solution was adjusted by caluculating the value of each water control (-- $\mathbf{- -})$ to $10 \mu \mathrm{mhos}$.

\section{Effect of AK-toxin on penetration of avirulent $A$. kikuchiana in pear leaves}

Avirulent spores plus AK-toxin $(1 \mu \mathrm{g} / \mathrm{ml}$ and $0.01 \mu \mathrm{g} / \mathrm{ml})$ were placed on pear leaves and the leaves were sectioned at various times. At a concentration of $1 \mu \mathrm{g} / \mathrm{ml}$, the avirulent spores could invade susceptible tissues within $8 \mathrm{hr}$ after inoculation, just as did the virulent spores. Visible black and necrotic pin head points on pear leaves were evident $12 \mathrm{hr}$ after inoculation. In susceptible leaves inoculated with avirulent spores plus AK-toxin at $0.01 \mu \mathrm{g} / \mathrm{ml}$, a few hyphae invaded into the epidermal cells after $24 \mathrm{hr}$, but did not show visible host cell responses. AK-toxin did not allow avirulent A. kikuchiana to colonize resistant tissues.

\section{Inoculation of Penicillium citrinum on pear leaves}

We have reported previously that citrinin, which is produced by $P$. citrinum, induces a similar host-specific veinal necrosis as that of $\mathrm{AK}$-toxin ${ }^{7}$. Therefore, pear leaves were sprayed with spore suspensions of $P$. citrinum. Although spores germinated on the pear leaves, infection was unsuccessful.

To test whether or not citrinin is released from germinating spores, spore suspensions were placed on glass slides. After incubation at $28 \mathrm{C}$ for $24 \mathrm{hr}$, the suspensions were collected with a pipet and attempts to extract citrinin were made by procedures described by Hetherington $e t a l^{2}$. Result showed that citrinin was detectable not from the germinating spores, but from the growing mycelia. 


\section{Discussion}

Morphological and histological studies in relation to A. kikuchiana with pear plant were first reported by Torikata ${ }^{15}$. Our observations agree in general with those of Torikata. Spores of A. kikuchiana germinated and formed appressoria equally on the susceptible and resistant pear leaves. Our previous data indicated that production of spore germination inhibitors or stimulators from pear leaves could not account for resistance ${ }^{9)}$. Germinating hyphae from the virulent A. kikuchiana isolate could penetrate the epidermal cells of susceptible leaf at 8-12 hr after inoculation and then spread in susceptible mesophyll tissues. Invasion in resistant tissues was confined to a few epidermal cells at $24 \mathrm{hr}$ after inoculation.

Virulent spores synthesized and released AK-toxin in sufficient concentrations to disturb the host cells, immediately afer germination. Avirulent spores did not produce toxin. Invasion of susceptible and resistant pears by an avirulent isolate was the same as those described for virulent spore on resistant pear. When the avirulent spores were inoculated together with AK-toxin, the hyphae invaded into host tissues, in same way as did the hyphae of virulent spores on susceptible pear. Thus, AK-toxin from germinating spores appears to be required by the fungus for invasion into host cells.

The first detectable physiological effect of A. kikuchiana on susceptible tissues was an increase in loss of electrolytes. The careful determination in electrolyte losse showed two different phases: at $2-6 \mathrm{hr}$ and at $9 \mathrm{hr}$ after inoculation. The first change apparently preceded epidermal penetration, which was observed $8 \mathrm{hr}$ after inoculation. AK-toxin has a rapid effect on the function of plasma membrane of the susceptible cultivars, and evidence for such an effect is the almost instantaneous increase in loss of electrolytes from susceptible tissues ${ }^{4,9,10,11)}$. Therefore, the data leads to the conclusion that the increase of electrolytes after 2-6 hr of inoculation is caused by AK-toxin from germinating spores prior to invasion, and suggests an effect on cell membranes. The second increase in electrolytes after $9 \mathrm{hr}$ could be the membrane disruption of sub-infected host tissues, due to AK-toxin from the invading hyphae. Observations with the electron microscope indicated that inoculation of pear leaves with A. kikuchiana causes invagination and lomasome-like vesicle only on susceptible plasma membrane within $6 \mathrm{hr}$ after inoculation ${ }^{13)}$. Such changes of plasma membrane are also observable by AK-toxin treatment ${ }^{13)}$.

Importance of AK-toxin productivity from germinating spores prior to host invasion can be enhanced by the following results, also. Citrinin produced by Penicillium citrinum, induces a similar host-specific toxicity as that AK-toxin ${ }^{7}$. Spores of $P$. citrinum germinated and the hyphae grew well on the surface of pear leaves, but there was no attempt to penetrate and no visible effect on leaf tissues. It was evident that citrinin can be produced only from the growing mycelia and not from the germinating spores. This point is quite different from AK-toxin productivity in A. kikuchiana. This may be one reason why $P$. citrinum can not serve as a pathogen to Japanese pear in nature. We have found recently the chemicals by which the AK-toxin production from spores could be switched off, and the spore germination could not be inhibited. When virulent spores of A. kikuchiana were suspended in the solution of the chemical and were inoculated to pear leaves, the appearance of disease symptom decreased 
obviously, although the inoculated spores germinated normally on the leaves (unpublished).

Results of our experiments on A. kikuchiana are somewhat consistent with those of Helminthosporium victoriae and $H$. carbonum. HV-toxin released by $H$. victoriae, causes the initial changes in host cell physiology characteristic of disease development ${ }^{16,17)}$. H. carbouum and HC-toxin have much more subtle effects; it supports a possibility that dead or seriously damaged cell are not required for successful colonization ${ }^{1)}$. However, $\mathrm{HV}$-toxin and HC-toxin are required for initial colonization of susceptible plants by each pathogen ${ }^{1,16,17)}$. Our results on $A$. kikuchiana indicate that AK-toxin from germinating spores prior to host invasion must be considered as an initial inciting agent of the disease establishment, and must be required not for killing of host cells, but for slight disruption on host membrane system, to establish the infection.

\section{Acknowledgement}

We are indebted to Drs. G. W. Steiner and J. C. Comstock, Hawaiian Sugar Planters' Association, for review of the manuscript.

\section{Literature cited}

1) Comstock, J. C. and Scheffer, R. P. (1973). Phytopathology 63: 24-29.

2) Hetherington, A. C. and Raistrick, H. (1931). Phil. Trans. Roy. Soc., (London) 220 B : 269.

3) Hiroe, I., Nishimura, S. and Sato, M. (1958). Trans. Tottori Soc. Agr. Sci. 11: 291-299.

4) Kasai, T., Otani, H., Kohmoto, K. and Nishimura, S. (1975). Jour. Fac. Agr. Tottori Univ. $10: 6-14$.

5) Kinoshita, T., Renbutsu, Y., Khan, I. D., Kohmoto, K. and Nishimura, S. (1972). Ann. Phytopath. Soc. Japan 38: 397-404.

6) Kozaki, I. (1973). Bull. Hort. Research Station, Japan, Series A 12: 17-27.

7) Nishimura, S. and Kohmoto, K. (1974). Ann. Phytopath. Soc. Japan 40:174 (abstr.).

8) Nishimura, S., Kohmoto, K., Otani, H., Fukami, H. and Ueno, T. (1974). Abstr. No. 53, Ist Intersectional Congress of IAMS, Tokyo.

9) Otani, H., Nishimura, S. and Kohmoto, K. (1972). Jour. Fac. Agr. Tottori Univ. $7:$ 5-12.

10) Otani, H., Nishimura, S. and Kohmoto, K. (1973). Ibid. 8: 14-20.

11) Otani, H., Nishimura, S. and Kohmoto, K. (1974). Ann. Phytopath. Soc. Japan 40:59-66.

12) Otani, H., Yano, K., Nishimura, S. and Kohmoto, K. (1974). Ibid. 40 : 174-175 (abstr.).

13) Park, P. (1974). Proceedings of Post IAMS Congress Osaka Symposium on Phytopathology, Osaka. 32-35.

14) Tanaka, S. (1933). Mem. College Agr. Kyoto Imp. Univ. 28: 1-31.

15) Torikata, H. (1957). Studies on the Mechanism of Susceptibility of Japanese Pears to the Black Spot Disease. (Personal Publication), Nagoya. 117 p.

16) Yoder, O. C. and Scheffer, R. P. (1969). Phytopathology 59 : 1954-1959.

17) Yoder, O. C. (1972). Phytotoxins in Plant Diseases (Wood, R. K. S. et al. ed.). Academic Press, London. pp. 457-463. 


\title{
和文摘 要
}

\author{
ナシ黒斑病菌の宿主特異的作用機構 $(\mathrm{V})$ \\ ナシ黒斑病感染初期に打ける宿主特異的毒素の役割 \\ 尾谷浩・西村正暘 - 甲元啓介 \\ 矢野清 · 瀬野武治
}

ナシ黒斑病に拈ける感染成立機構の解析を目的として，宿主特異的毒素 (AK-毒素) の感染初期に果たす 役割について検討した。感受性 (二十世紀)，抵抗性 (長十郎) ナシ葉に接種した黒班病菌の胞子は，1時間で発 芽を開始したが，その後の両ナシ葉上での菌の行動には，顕著な差は認められなかった。接種後 8 12 時間頃 に, 病原性菌株の胞子を接種した感受性品種では, 表皮細胞への微感染が観察された。病原性菌株の胞子は, 発芽とともに徐々に $\mathrm{AK}$-毒素を放出し，接種後 4 時間では，すでに 1 胞子当り約 100 個の宿主細胞を失活さ せらる毒素量に達した。AK-毒素は, 感受性品種に細胞膜透過性の異常増大を引き起こすが，病原性菌株の胞 子を接種した感受性品種では，接種後 2 6 時間で第一の透過性の増大が，さらに，9時間頃 (微感染時) から は, 第二の急激な異常増大が認められた。病原性失活菌株の胞子に AK-毒素を加えて接種すると, 病原性菌 と同様な透過性の増大を引き起こし，宿主細胞における微感染も誘発された。Penicillium citrinum の代謝 産物であるシトリニンは，ナシ品種に対して AK-毒素と類似の反応を示すが，シトリニンは，P. citrinum 胞子の発芽時には分泌されず，胞子接種によるナシ葉への感染は認められなかった。

以上の結果から，ナシ黒斑病に打ける感染成立の可否は，胞子発芽直後の AK-毒素によって決定され， AK-毒素による宿主細胞のわずかな細胞膜機能の破壊が，菌の侵入に導くものと推察された。 